\title{
Classification of Andrographis paniculata extracts by solvent extraction using HPLC fingerprint and chemometric analysis
}

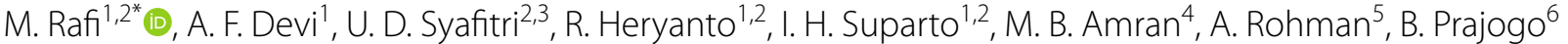 \\ and L.W. Lim ${ }^{7}$
}

\begin{abstract}
Objective: Andrographis paniculata, widely used as an antidiabetic in Indonesian traditional medicines (jamu), contains chemical compounds whose concentration is related to its therapeutic effects. The concentration of solvents used for extraction will also affect the number of compounds extracted. Therefore, a quality control method is needed to ensure consistency in quantifying these compounds in A. paniculata to improve its therapeutic application. High-performance liquid chromatography fingerprint analysis combined with chemometrics was used to evaluate extracts from different solvent extraction treatments. The content of andrographolide, the main bioactive compound in A. paniculata, and the level of a-glucosidase inhibition activity, an indicator of its antidiabetic activity, were also determined.

Results: Fingerprint chromatograms of A. paniculata extracts from different treatments exhibited a similar pattern with several peaks in common, only differing in area and intensity value. The A. paniculata extracts were classified using HPLC fingerprint and principal component analysis to allow grouping according to their respective solvent extraction treatments. The highest andrographolide content and a-glucosidase inhibition activity occurred in the 50\% ethanol extract and the lowest in the water extract. HPLC fingerprint analysis could be used for identifying A. paniculata extracts based on solvent extraction, thus improving quality control for their therapeutic application.
\end{abstract}

Keywords: A. paniculata, Classification, HPLC fingerprint analysis, Principal component analysis

\section{Introduction}

Andrographis paniculata, commonly known as green chiretta or, in Indonesian, as sambiloto, is a medicinal plant often used in Indonesia for treating diabetes. The plant tastes very bitter so is known as 'king of bitters'. Its major biological activity is antidiabetic [1] but it has also been reported to have anti-angiogenetic [2], antibacterial [3], anti-cancer [4], anti-inflammatory [5, 6], antimalarial [7], antioxidant [8], and hepatoprotective activities [9].

\footnotetext{
*Correspondence: mra@apps.ipb.ac.id

${ }^{1}$ Department of Chemistry, Faculty of Mathematics and Natural

Sciences, Institut Pertanian Bogor, Jalan Tanjung Kampus IPB Dramaga,

Bogor 16680, Indonesia

Full list of author information is available at the end of the article
}

The biological activity of A. paniculata comes from its bioactive compounds, the main class being the diterpene lactone group, which includes andrographolide, dehydroandrographolide, neoandrographolide, and deoxyandrographolide. Andrographolide occurs in higher amounts than the other diterpene lactones in A. paniculata [10]. Flavonoids such as andrographidine, apigenin, and luteolin are also present in A. paniculata [11].

The composition and concentration of chemical compounds in plants are affected by factors such as genetics, environmental growth conditions, and the harvest and post-harvest conditions. The type of solvent used for extraction and its concentration play an important role in the amounts of bioactive compound extracted [12].

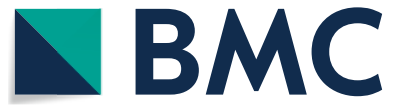

(c) The Author(s) 2020. This article is licensed under a Creative Commons Attribution 4.0 International License, which permits use, sharing, adaptation, distribution and reproduction in any medium or format, as long as you give appropriate credit to the original author(s) and the source, provide a link to the Creative Commons licence, and indicate if changes were made. The images or other third party material in this article are included in the article's Creative Commons licence, unless indicated otherwise in a credit line to the material. If material is not included in the article's Creative Commons licence and your intended use is not permitted by statutory regulation or exceeds the permitted use, you will need to obtain permission directly from the copyright holder. To view a copy of this licence, visit http://creativeco mmons.org/licenses/by/4.0/. The Creative Commons Public Domain Dedication waiver (http://creativecommons.org/publicdomain/ zero/1.0/) applies to the data made available in this article, unless otherwise stated in a credit line to the data. 
Effective quality control of compounds extracted from medicinal plants is needed to ensure the consistency of their biological activity which is related to their content. Two approaches are mainly used for the quality control of medicinal plant extracts: marker and fingerprint analysis [13]. These two approaches have advantages and can be used together to obtain reliable evaluations for the quality control of medicinal plants. Therefore the present study used these two approaches combined with chemometrics to classify extracts from $A$. paniculata.

Several previous studies have reported data on the composition and levels of chemical compounds, and certain biological activities of $A$. paniculata extracts [14-17]. However, the effect of different concentrations of extraction solvent on the levels of marker compounds (andrographolide), chemical fingerprinting and the inhibition of $\alpha$-glucosidase has not yet been reported for $A$. paniculata. Therefore, the present study aims to investigate the effect of solvent extraction concentration on the chemical compounds extracted from $A$. paniculata using HPLC and the inhibitory effects of these compounds on $\alpha$-glucosidase.

\section{Main text}

\section{Materials and methods}

Materials and chemicals

Andrographis paniculata was collected from the Pusat Studi Biofarmaka Tropika medicinal plant garden (Bogor, Indonesia) in 2019. Andrographolide (purity > 99.8\%) was obtained from ChromaDex Inc. (Santa Ana, CA, USA); ethanol, acetonitrile HPLC grade, and formic acid from Merck (Darmstadt, Germany); Whatman membrane filters $(0.22 \mu \mathrm{m}$ pore size; PTFE; P/N E252, Little Chalfont, UK) for filtration of sample solutions; and alpha-glucosidase and $p$-nitrophenyl- $\alpha$-D-glucopyranoside (PNG), phosphate buffer ( $\mathrm{pH} 7)$, dimethyl sulfoxide (DMSO), and $\mathrm{Na}_{2} \mathrm{CO}_{3}$ from Sigma Aldrich (St Louis, MO, USA).

\section{Sample preparation and extraction}

The samples of $A$. paniculata, collected 3 months previously, were first sorted then cleaned by washing in water. The samples were then dried and pulverized to a powder. About $10 \mathrm{~g}$ of the powder was added to $100 \mathrm{~mL}$ of the extraction solvent then soaked with continuous stirring for $6 \mathrm{~h}$ then left for a further $12 \mathrm{~h}$ without stirring. The solvents used for extraction were water, and solutions of $30 \%, 50 \%, 70 \%$ and pure ethanol. The filtrate was collected, concentrated with a rotary evaporator, then dried in a freeze-dryer.

\section{Determination of a-glucosidase inhibition activity}

About $10 \mathrm{mg}$ of $A$. paniculata extract was dissolved using $1 \mathrm{~mL}$ DMSO. Fifty $\mu \mathrm{L}$ of $0.1 \mathrm{M}$ phosphate buffer
(pH 7), $25 \mu \mathrm{L}$ of $10 \mathrm{mM}$ PNG and $25 \mu \mathrm{L}$ of $\alpha$-glucosidase $(0.04 \mu / \mathrm{mL})$ were added to $10 \mu \mathrm{L}$ of the sample solution followed by incubation for $30 \mathrm{~min}$ at $37{ }^{\circ} \mathrm{C}$. The reaction was terminated by adding $100 \mu \mathrm{L}$ of $0.2 \mathrm{M} \mathrm{Na}_{2} \mathrm{CO}_{3}$. The enzymatic hydrolysis of the substrate to produce p-nitrophenol was monitored at $410 \mathrm{~nm}$ using an Epoch microplate spectrophotometer (BioTek Instruments Inc. Winooski, VT, USA). A blank sample and each sample extract were analyzed in triplicate.

\section{HPLC conditions}

The HPLC conditions were the same as those described by Song et al. [10] with some modifications. An HPLC LC-20 AD equipped with a Shimpack VP ODS C18 column (150 $\mathrm{nm} \times 4.6 \mathrm{~mm}$ i.d.) (Shimadzu, Kyoto, Japan) was used to separate the compounds in the $A$. paniculata extracts. The mobile phase used consisted of $0.1 \%$ formic acid in acetonitrile (A) and $0.2 \%$ formic acid in water (B). The gradient elution was programmed as follows: $10-30 \%$ (A) from 0 to $30 \mathrm{~min}, 30-85 \%$ (A) from 30 to $55 \mathrm{~min}$, then $85 \%$ (A) from 55 to $60 \mathrm{~min}$. The mobile phase was filtered using a Whatman filter membrane $(0.45 \mu \mathrm{m})$ and sonicated for $30 \mathrm{~min}$ before use. The flow rate was $1 \mathrm{~mL} / \mathrm{min}$, and the injection volume $20 \mu \mathrm{L}$, with the separation being monitored at $254 \mathrm{~nm}$.

\section{Preparation of sample solutions}

The sample solutions were prepared by weighing $10 \mathrm{mg}$ of the dried extract, adding $5 \mathrm{~mL}$ of $50 \%$ methanol (HPLC grade), followed by sonication for $1 \mathrm{~h}$. The sample solutions were then diluted with $10 \mathrm{~mL}$ of $50 \%$ methanol and filtered through a $0.45-\mu \mathrm{m}$ membrane filter before injection into the HPLC system. The five different sample solutions ( $0 \%$ as control, 30\%, 50\%, 70\% and pure ethanol) were prepared then injected into the HPLC.

\section{Determination of andrographolide content}

The andrographolide content of each extract was determined. A series of standard solutions at five concentrations of andrographolide was made in from 10 to $140 \mu \mathrm{g} /$ $\mathrm{mL}$ to construct a calibration curve. The andrographolide content was quantified using the calibration curve with triplicate measurements.

\section{Classification of $A$. paniculata extracts}

Principal component analysis (PCA) was used to classify the A. paniculata extracts. Unscrambler X (version 10.1, CAMO, Oslo, Norway) was used to construct the PCA model using the areas of the eight major peaks from each extract. 


\section{Results and discussion}

\section{Extraction and inhibition of a-glucosidase activity}

The compounds from $A$. paniculata were extracted by maceration at room temperature. The results showed that the extraction yield using different concentrations of ethanol and water solvents differed slightly (Table 1). The highest yield was obtained using 50\% ethanol, and the lowest using water, indicating that different concentrations of solvent extraction affected the level of metabolite extracted.

Table 1 Effect of solvent concentration on a-glucosidase inhibitory activity and andrographolide yield from $A$. paniculata extracts

\begin{tabular}{lcc}
\hline Extraction solvent & $\begin{array}{l}\text { Inhibition } \\
(\% \pm \text { SD) }\end{array}$ & $\begin{array}{l}\text { Andrographolide } \\
\text { content } \\
\text { (mg/g } \pm \text { SD) }\end{array}$ \\
\hline Water & $54.80 \pm 4.05$ & $25.18 \pm 1.49$ \\
$30 \%$ ethanol & $58.42 \pm 2.41$ & $50.29 \pm 1.43$ \\
$50 \%$ ethanol & $79.66 \pm 6.45$ & $114.56 \pm 2.30$ \\
70\% ethanol & $60.02 \pm 0.32$ & $96.48 \pm 0.89$ \\
Pure ethanol & $49.58 \pm 0.97$ & $102.08 \pm 2.73$
\end{tabular}

a Average of 2 replicates

b Average of 3 replicates
The effect of different extraction solvent concentrations on $\alpha$-glucosidase inhibitory activity was also determined. The assay was based on the principle that $\alpha$-glucosidase will hydrolyze glucose in the substrate ( $p$-nitrophenyl$\alpha$-D-glucopyranoside) to $\alpha$-D-glucose and $p$-nitrophenol so that inhibitory activity can be measured based on the amount of $p$-nitrophenol produced. Table 1 shows that $\alpha$-glucosidase inhibitory activity was highest in the $50 \%$ ethanol extract followed by $70 \%, 30 \%$ ethanol, water and pure ethanol. This result showed that a combination of water and ethanol could extract more polar and semipolar compounds that are known to have $\alpha$-glucosidase inhibitory activity.

\section{HPLC fingerprint and andrographolide content}

Each extract from $A$. paniculata was analyzed using HPLC to determine the effect of the extraction solvent concentration on the composition of the extracted metabolites. Figure 1 shows the fingerprint chromatogram of the A. paniculata extracts. Overall, 23 peaks with a percentage area of more than $5 \%$ were detected in the extracts. Peak 15 (andrographolide) was the major peak in $A$. paniculata with the highest intensity and peak area in all extracts. The fingerprint chromatograms obtained of all samples had a similar pattern with peaks $2,7,8$,

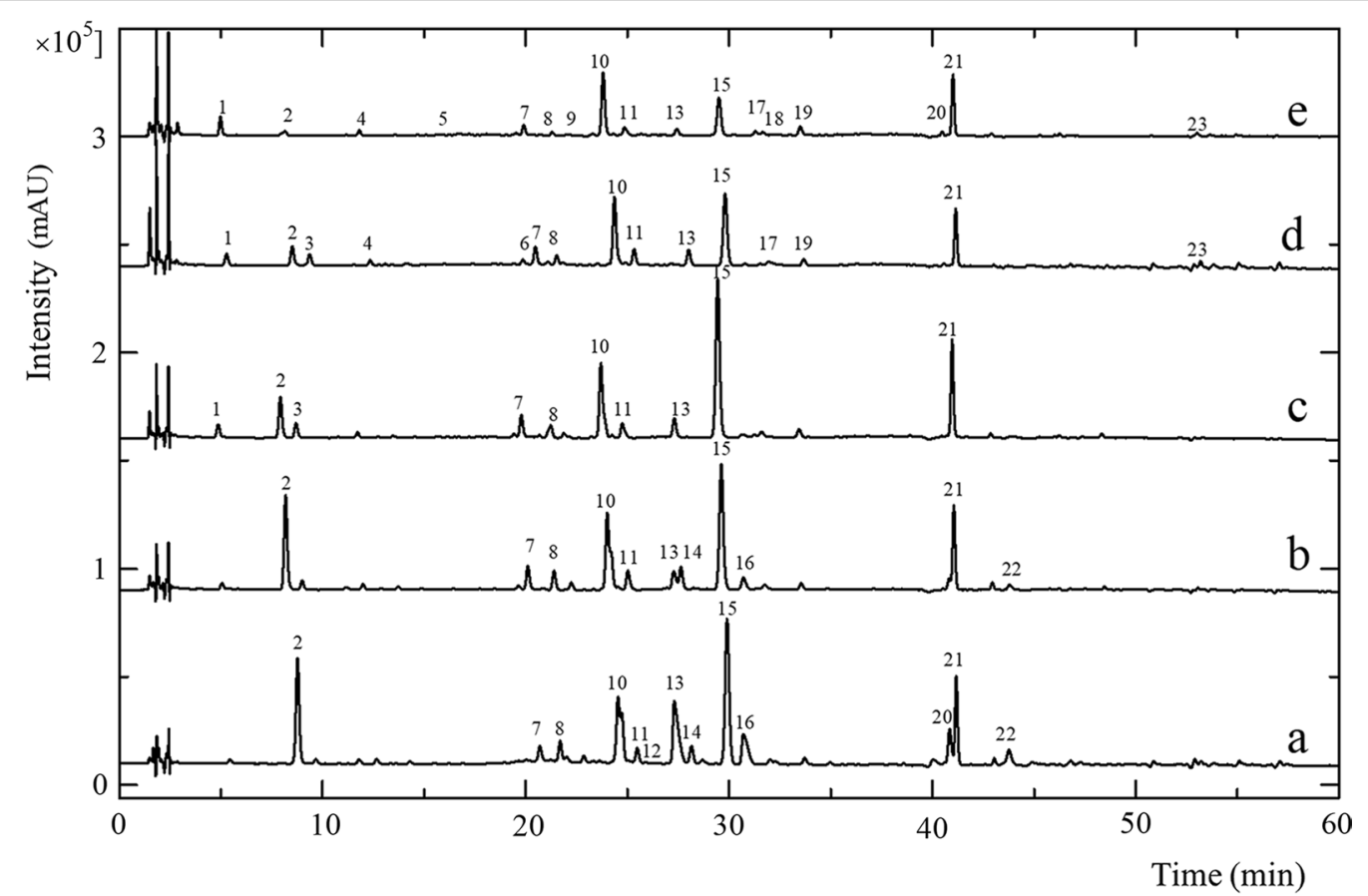

Fig. 1 HPLC chromatograms of A. paniculata extracts using different solvents: (a) pure ethanol, (b) 70\% ethanol, (c) 50\% ethanol, (d) 30\% ethanol and (e) water 
$10,11,13,15$, and 21 appearing in every sample extract. The differences between the peaks were mostly in peak height and area because each solvent used for extraction exhibited a different polarity and ability for extracting the chemical compounds.

Another difference was that some peaks, such as peaks 12 and 22, appeared only in the ethanol extract thus indicating a typical peak for the fingerprint pattern of ethanol extracts. Peak 1 also appeared in the 30\%, 50\% ethanol, and water extracts. The extraction solvents with a greater polarity also led to a greater number of detected peaks, the water extracts exhibiting more detected peaks than the other extracts (Fig. 1). These results agreed with a previous study that adding more water to ethanol increased its polarity, thus increasing the yield of diterpenoid lactones [18].

Andrographolide is one of the main bioactive compounds present in $A$. paniculata. The present study determined the andrographolide levels in extracts from five different treatments (Table 1). The highest andrographolide levels were found in the $50 \%$ ethanol extract, followed by pure ethanol, $70 \%$ ethanol, $30 \%$ ethanol, with the lowest in the water extract. These results indicated that the amount of andrographolide extracted depended on the polarity of the extraction solvent. A previous study has shown that andrographolide has a lactone ring which is chemically very vulnerable, reactive and easily rearranged. Opening the lactone ring of andrographolide is the initial stage of the decomposition process. In water, this ring opening occurs through hydrolysis, whereas in ethanol it occurs through a trans-esterification mechanism, with hydrolysis being faster than transesterification. Therefore, the rate of andrographolide decomposition depends on the type of solvent. Kumoro et al. [18] reported that adding water leads to the conversion of andrographolide to deoxyandrographolide through the hydrolysis process, thus reducing the andrographolide levels in the extracts.

\section{Classification of $A$. paniculata extracts}

The HPLC fingerprint chromatograms for the $A$. paniculata extracts used in the present study exhibited a similar pattern, only differing in the peak height and area which corresponded with the level of compound extracted by the different solvent extraction treatments. Differentiating treatments based on HPLC fingerprint chromatograms alone is not easy, so chemometrics analysis is also necessary. Principal component analysis (PCA) can be used to classify or group the extracts according to their solvent extraction treatment. The peak area of the eight major peaks (Peaks 2, 7, 8, 10, 11, 13, 15, and 21) were used as a variable.

Before using PCA, the variable was pretreated by autoscaling. Pretreatment of data is an important step before chemometric analysis to obtain a meaningful result because the quality of the input data greatly affects the quality of the output of the analysis. A common autoscaling method uses the standard deviation as a scaling factor to produce a good analytical output from PCA chemometric analysis techniques [19].

Using PCA, the samples were grouped according to their solvent extraction treatment based on their chemical composition. This multivariate analysis works by simplifying the observed variables by reducing the number of dimensions to give an overview of sample groups using the principal component (PC) [20]. Figure 2a shows the PCA score plot for the $A$. paniculata extracts where the extracts were grouped according to their solvent extraction treatment. Samples with a similar profile of the metabolite will be grouped together and those with a dissimilar profile will form a separate group. The two principal components, PC1 and PC2, explaining most of the variance are used in the analysis. In the present study, the cumulative percentage of the two PCs used was $89 \%$ of the total variance. According to Varmuza [21], if the cumulative percentage of $\mathrm{PC} 1$ and $\mathrm{PC} 2$ is greater than $70 \%$, the score plot offers a good two-dimensional visualization.

The PCA biplot is a combination of the score and loading plots. The loading plot provides information on how strongly each variable affected the principal component. Figure $2 \mathrm{~b}$ shows the PCA biplot of the A. paniculata extracts with the variables which contributed most to its grouping. We found that peaks 5 and 7 contributed strongly to the grouping of the $50 \%$ and $70 \%$ ethanol extracts of $A$. paniculata.

\section{Conclusion}

The HPLC fingerprint chromatograms of the $A$. paniculata extracts exhibited a similar pattern which differed only in the peak height and area of each detected peak. The $50 \%$ ethanol extract provided a higher andrographolide content and percentage $\alpha$-glucosidase inhibitory activity than the other extracts. Combining the HPLC fingerprint technique with PCA enabled the $A$. paniculata extracts to be classified according to their solvent extraction.

\section{Limitation}

The modified HPLC method was not verified. 
a
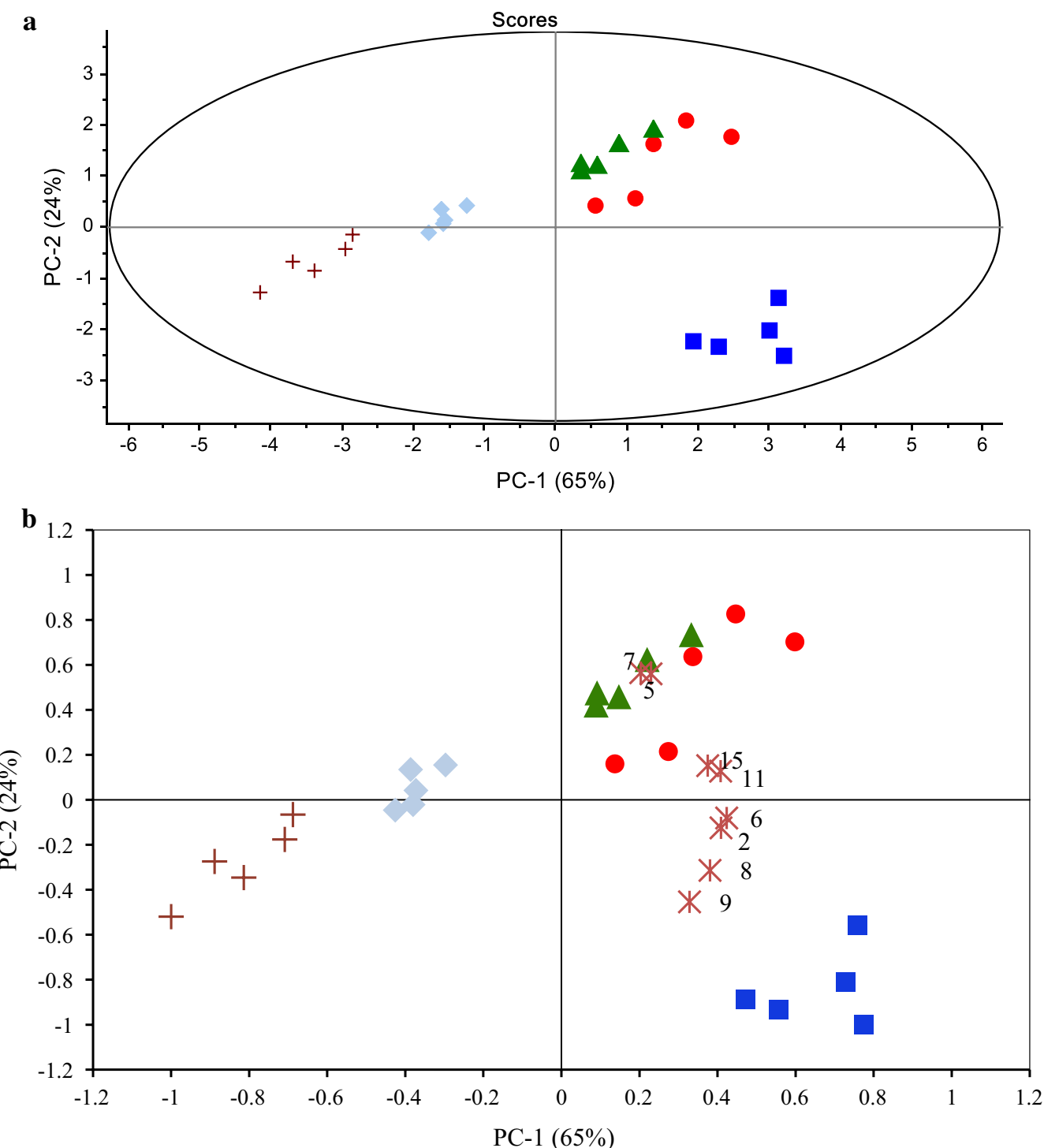

Fig. 2 a PCA plot and $\mathbf{b}$ PCA biplot of A. paniculata extracts using different solvents: pure ethanol ( $\square$ ), 70\% ethanol ( ), 50\% ethanol (山), 30\% ethanol $(\diamond)$, water $(+)$, and variable (peak number) $(\mathbb{X})$

\section{Abbreviations}

DMSO: Dimethyl sulfoxide; HPLC: High-performance liquid chromatography; PCA: Principal component analysis; PC: Principal component; PNG: D-Glucopyranoside.

\section{Acknowledgements}

We would like acknowledge the contribution to this study of Mrs Laila Wulansari, laboratory technician at the Pusat Studi Biofarmaka Tropika Institut Pertanian Bogor. We thank Philip Creed, PhD, from Edanz Group (http://www. edanzediting.com/ac) for editing a draft of this manuscript.

\section{Authors' contributions}

MR designed and performed the research, and was the major contributor in writing the manuscript; AFD collected the samples and performed the research; UDS designed the research, and analyzed the data; $\mathrm{RH}$ performed the research and wrote the manuscript; IHS designed and performed the research; MBA analyzed the data and wrote the manuscript; AR analyzed the data and wrote the manuscript; BP wrote and checked the manuscript; LWL wrote and checked the manuscript. All authors read and approved the final manuscript.

\section{Funding}

This work was supported by a Penelitian Unggulan Perguruan Tinggi Grant 2018 (No: 1764/IT3.L1/PN/2018) from the Ministry of Research, Technology, and Higher Education, Republic of Indonesia and partly supported by a Riset Kolaborasi Indonesia Grant 2019 (No: 0847/IT3.L1/PN/2019) World Class University Program of Institut Pertanian Bogor. The funding bodies has no role in the design of the study and collection, analysis, interpretation of data and manuscript writing.

\section{Availability of data and materials}

The data can be requested from the corresponding author.

Ethics approval and consent to participate

No human or animal studies were used in this work. 


\section{Consent for publication}

Not applicable.

\section{Competing interests}

The authors declare that they have no competing interests.

\begin{abstract}
Author details
${ }^{1}$ Department of Chemistry, Faculty of Mathematics and Natural Sciences, Institut Pertanian Bogor, Jalan Tanjung Kampus IPB Dramaga, Bogor 16680, Indonesia. ${ }^{2}$ Tropical Biopharmaca Research Center, Institut of Research and Community Empowerment, Institut Pertanian Bogor, Jalan Taman Kencana No. 3 Kampus IPB Taman Kencana, Bogor 16128, Indonesia. ${ }^{3}$ Department of Statistics, Faculty of Mathematics and Natural Sciences, Institut Pertanian Bogor, Jalan Meranti Kampus IPB Dramaga, Bogor 16680, Indonesia. ${ }^{4}$ Analytical Research Chemistry Group, Institut Teknologi Bandung, Jalan Ganesha No 10, Bandung 40132, Indonesia. ${ }^{5}$ Department of Pharmaceutical Chemistry, Faculty of Pharmacy, Universitas Gadjah Mada, Sekip Utara, Yogyakarta 55281, Indonesia. ${ }^{6}$ Department of Pharmacognosy and Phytochemistry, Faculty of Pharmacy, Universitas Airlangga, Jl Mulyorejo Kampus C Unair, Surabaya 60286 , Indonesia. ${ }^{7}$ Department of Chemistry and Biomolecular Science, Faculty of Engineering, Gifu University, 1-1 Yanagido, Gifu 501-1193, Japan.
\end{abstract}

Received: 27 November 2019 Accepted: 24 January 2020

Published online: 04 February 2020

\section{References}

1. Subramanian R, Asmawi MZ, Sadikun A. In vitro a-glucosidase and a-amylase enzyme inhibitory effects of Andrographis paniculata extract and andrographolide. Acta Biochim Pol. 2008;55(2):391-8. https://doi. org/10.18388/abp.2008_3087.

2. Sheeja K, Guruvayoorappan C, Kuttan G. Antiangiogenic activity of Andrographis paniculata extract and andrographolide. Int Immunopharmacol. 2007;7:211-21. https://doi.org/10.1016/j.intimp.2006.10.002.

3. Mishra PK, Singh RK, Gupta A, Chaturvedi A, Pandey R, Tiwari SP, Mohapatra TB. Antibacterial activity of Andrographis paniculata (Burm. f.) Wall ex Nees leaves against clinical pathogens. J Pharm Res. 2013;7(5):459-62. https://doi.org/10.1016/j.jopr.2013.05.009.

4. Paul T, Basu S, Saha NC. Anticancer effect of Andrographis paniculata by suppression of tumor altered hypoxia signaling cascade in mouse melanoma cells. J Cancer Res Pract. 2019;6(3):117-23. https://doi.org/10.4103/ JCRP.JCRP_9_19.

5. Low M, Khoo CS, Münch G, Govindaraghavan S, Sucher NJ. An in vitro study of anti-inflammatory activity of standardised Andrographis paniculata extracts and pure andrographolide. BMC Complement Altern Med. 2015;15:18. https://doi.org/10.1186/s12906-015-0525-7.

6. Zou W, Xiao Z, Wen X, Luo J, Chen S, Cheng Z, Xiang D, Hu J, He J. The anti-inflammatory effect of Andrographis paniculata (Burm. f.) Nees on pelvic inflammatory disease in rats through down-regulation of the NF-kB pathway. BMC Complement Altern Med. 2016;16:483. https://doi. org/10.1186/s12906-016-1466-5

7. Zein U, Fitri LE, Saragih A. Comparative study of antimalarial effect of sambiloto (Andrographis paniculata) extract, chloroquine, and artemisinin and their combination against Plasmodium falciparum in vitro. Acta Med Indones. 2013;45:38-43.

8. Kurzawa M, Filipiak-Szok A, Kłodzińska E, Szłyk E. Determination of phytochemicals, antioxidant activity and total phenolic content in Andrographis paniculata using chromatographic methods. J Chromatogr B. 2015;995996:101-6. https://doi.org/10.1016/j.jchromb.2015.05.021.

9. Bardi DA, Halabi MF, Hassandarvish P, Rouhollahi E, Paydar M, Moghadamtousi SZ, Al-Wajeeh NS, Ablat A, Abdullah NA, Abdulla MA. Andrographis paniculata leaf extract prevents thioacetamide-induced liver cirrhosis in rats. PLoS ONE. 2014;9(10):e109424. https://doi.org/10.1371/journ al.pone.0109424.

10. Dong HJ, Zhang ZJ, Yu J, Liu Y, Xu FG. Chemical fingerprinting of Andrographis paniculata (Burm. F.) Nees by HPLC and hierarchical clustering analysis. J Chromatogr Sci. 2009;47(10):931-5. https://doi.org/10.1093/ chromsci/47.10.931.
11. Chen LX, He H, Xia GY, Zhou KL, Qiu F. A new flavonoid from the aerial parts of Andrographis paniculata. Nat Prod Res. 2014;28(3):138-43. https:// doi.org/10.1080/14786419.2013.856907.

12. Sultana B, Anwar F, Ashraf M. Effect of extraction solvent/technique on the antioxidant activity of selected medicinal plant extracts. Molecules. 2009;14:2167-80. https://doi.org/10.3390/molecules14062167.

13. Li S, Han Q, Qiao C, Song J, Cheng CL, Xu H. Chemical markers for the quality control of herbal medicines: an overview. Chin Med. 2008;3:7. https://doi.org/10.1186/1749-8546-3-7.

14. Ahmad M, Razak A, Akowuah GA, Asmawi Z, Zhari I. HPLC profile and antihyperglycemic effect of ethanol extracts of Andrographis paniculata in normal and streptozotocin-induced diabetic rats. J Nat Med. 2007;61(4):422-9. https://doi.org/10.1007/s11418-007-0157-4.

15. Song YX, Liu SP, Jin Z, Qin JF, Jiang ZY. Qualitative and quantitative analysis of Andrographis paniculata by rapid resolution liquid chromatography/ time-of-flight mass spectrometry. Molecules. 2013;18(10):12192-207. https://doi.org/10.3390/molecules181012192.

16. Chua LS, Yap KC, Jaganath IB. Comparison of total phenolic content, scavenging activity and HPLC-ESI-MS/MS profiles of both young and mature leaves and stems of Andrographis paniculata. Nat Prod Comm. 2013;8(12):1725-9. https://doi.org/10.1177/1934578X1300801217.

17. Zhao Y, Kao CP, Wu KC, Liao CR, Ho YL, Chang YS. Chemical compositions, chromatographic fingerprints and antioxidant activities of Andrographis herba. Molecules. 2014;19(11):18332-50. https://doi.org/10.3390/molec ules191118332

18. Kumoro AC, Hasan M, Singh $\mathrm{H}$. Effects of solvent properties on the Soxhlet extraction of diterpenoid lactones from Andrographis paniculata leaves. Sci Asia. 2009;35:306-9. https://doi.org/10.2306/scienceasia1513 $-1874.2009 .35 .306$.

19. Van den Berg RA, Hoefsloot HCJ, Westerhuis JA, Smilde AK, van der Werf MJ. Centering, scaling, and transformations: improving the biological information content of metabolomics data. BMC Genomics. 2006;7:142. https://doi.org/10.1186/1471-2164-7-142.

20. Theodoridis GA, Gika HG, Want EJ, Wilson ID. Liquid chromatographymass spectrometry based global metabolite profiling: a review. Anal Chim Acta. 2012;711:7-16. https://doi.org/10.1016/j.aca.2011.09.042.

21. Varmuza K. Applied chemometrics: from chemical data to relevant information. In: 1st Conference on Chemistry. 6-9 March 2000, Cairo University, Cairo, Egypt. 2001. https://pdfs.semanticscholar.org/5e72/6a250 9281c594df5f047932c1a2239f58d52.pdf?_ga =2.207535504.2092514566 .1573564283-1125364511. Accessed 12 Nov 2019.

\section{Publisher's Note}

Springer Nature remains neutral with regard to jurisdictional claims in published maps and institutional affiliations.

Ready to submit your research? Choose BMC and benefit from:

- fast, convenient online submission

- thorough peer review by experienced researchers in your field

- rapid publication on acceptance

- support for research data, including large and complex data types

- gold Open Access which fosters wider collaboration and increased citations

- maximum visibility for your research: over 100M website views per year

At BMC, research is always in progress.

Learn more biomedcentral.com/submissions 